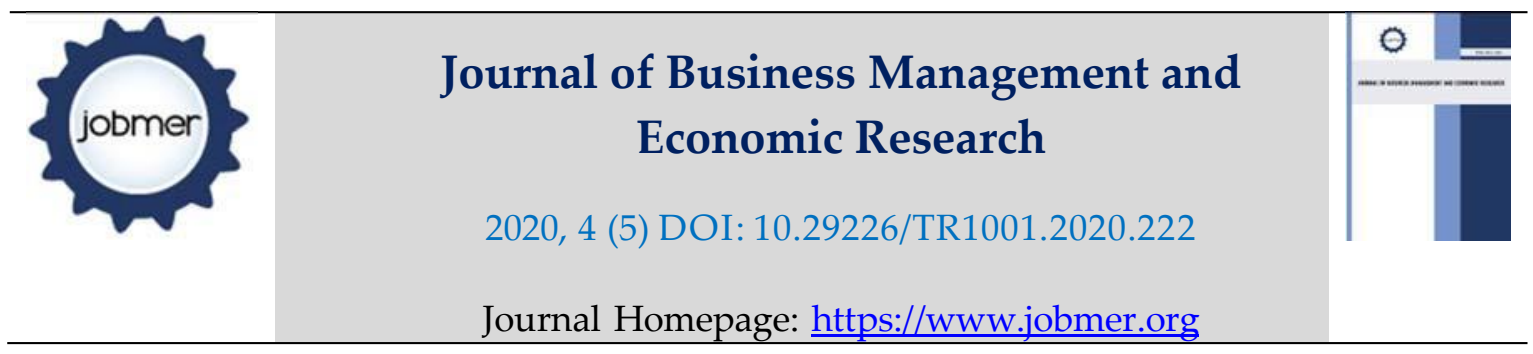

\title{
An Evaluation of Food Safety Practices of The Kitchen Staff Working in Hospitality Businesses: Kuşadası Case
}

\author{
Emrah Köksal SEZGİN \\ Departman of Hotel, Restaurant and Catering \\ Aydin Adnan Menderes University \\ Orcid number: /orcid.org/0000-0003-3165-7147 \\ ekoksalsezgin@gmail.com
}

\begin{abstract}
Aim of this research is to determine the opinions of kitchen staff about food safety at hotels in Kuşadası region they work and expose the relationship between those opinions and their demographical characteristics. With this aim, a survey has been applied to the staff and as a result, it was found that duty and working period of staff were effective.
\end{abstract}

Keywords: Food Safety, Hygiene, Food and Beverage Staff

\section{Introduction}

Food safety has become the most important social issue of recent years due to the awareness of the consumer in the old-fashioned food processing and presenting approaches to consumers and due to the fact that countries update the food laws in order to produce healthier and safer food. From a narrow perspective, although food safety is a concept used in the sense that it is prepared in accordance with its intended use and does not harm consumers when consumed, more broadly, it is a scientific system cycle that defines the processing, preparation, storage and delivery of food to end consumers, preventing biological, physical and chemical factors that cause foodborne diseases. In other respects, secure food is a food that has been made suitable for consumption by freeing from all kinds of spoilage and contamination.

Ensuring food safety in hotel kitchens depends on strict adherence to the principles of food hygiene and sanitation in all stages from production to transport, storage, preparation, cooking and service. Sanitation is the provision and maintenance of hygienic conditions in order to prevent food contamination and meet customer expectations. If the sanitation rules are not followed, the essential nutrients for human survival are contaminated, which can lead to illness or death. Hazard Analysis and Critical Control Points (HACCP) have been developed to ensure secure food production in many countries, particularly in the UK. Studies have reported that this method is the most effective way to assess the sanitation status of nutritional services. (Şimşek, 2006, p. 2). Public Hospitals in Kenya. Journal of Business Management and Economic Research (JOBMER), Vol: 4, Issue: 5 , 
Sanitation and hygienic conditions in a food and beverage business have a significant impact on customers' assessment of that business. It is seen that hygiene is among the first criteria that customers take into consideration in restaurant preferences. Therefore, it is a necessity that managers and other employees working in food and beverage departments should be knowledgeable and careful in providing hygiene. (Sargin, 2005, p. 4).

\section{Literature \\ Food Security}

Secure food can be defined as a foodstuff that is suitable for consumption in terms of its physical, chemical and microbiological properties and has not lost its nutritional value. Food security, on the other hand, can be defined as physical and economic access to adequate nutrients and providing sustainable agricultural production. We can also define food security as the right of people to obtain adequate, regular and nutritious food. Food security in its broadest sense is defined as "the physical and economic access to adequate, safe and nutritious food in order to meet the nutritional needs and food priorities required for an active and healthy life at all times and ensures their sustainability". (Hacioğlu \& Girgin, 2008, p. 282). However, many inaccuracies cause food to become harmful. Since food-borne diseases and their consequences are gaining increasing dimensions all over the world, the concerns of consumers are also increasing. Food damage is largely due to unhygienic food production. Such foods are harmful to human health by infecting various numbers of harmful microorganisms, excess pesticide residues or unwanted chemicals such as hormones and physical substances such as glass, stone, etc. (Şahin, 2001, p. 2).

One of the main service units of the Ministry of Agriculture and Rural Affairs is the General Directorate of Protection and Control (KORGEM), which is Common and sole authority on food safety in our country. KORGEM is the unit responsible for the implementation of food law (Giray v.d., 2006, p. 976). Quality control and management systems have been established in order to ensure the competitiveness and sustainability of competition in terms of food safety. These systems are "ISO 9000 Quality Standards" established by the International Organization for Standardization and "The Turkish Standard" established by the Turkish Standards Institute (TSE), established in 1960 and directly linked to the Prime Ministry. The TS 13001 Standard on food safety by TSE is based on the principles of internationally accepted Critical Control Points Hazard Analysis (HACCP). (Giray \& Sosyal, 2007, p. 487).

HACCP consisting of the initials of Hazard Analysis Critical Control Point is a systematic process that guarantees the safety of food products. It can be translated into Turkish as Hazard Analysis and Critical Control Points. The HACCP (Hazard Analysis Critical Control Points) concept was first developed in 1959 by the NASA (National Aeronautics and Space Administration) in the United States during the Apollo space flight. In 1974, the FDA (Food Drug Administration) of the United States required this system to be applied to low-acid canned food products, one of the highest-risk food groups in this system. In the early 1980s, many American food companies voluntarily implemented this system in their production. In 1985, the NAS (National Academy of Sciences) recommended the implementation of the HACCP system as a national food safety strategy in all food producing establishments, and the British soon adopted this systematic approach in 1990 as a framework food law "Food Security Regulations". In 1991, the Codex Alimentarius Committee on Food Hygiene, consisting of international FAO-WHO joint experts, initiated a guideline preparation attempt for the international applicability of the HACCP system and in 1993 the first guideline was published. In line with this development, the European Community included this first guide in the scope of 93/43 EC Council Directive on Hygiene of Foodstuffs, which was established in 1993 and it has made good hygiene practices a legal obligation for the food sector in h community countries. By the help of SPS (Sanitary and 
Phytosanitary Measures) Agreements performed by the World Trade Organization (WHO) and signed also by Turkey, the development of specific monitoring and control system for secure food production and implementation has been made mandatory to all countries engaged in food trade during the same years. (Karaali, 2003, p. 1).

HACCP is stated in the Turkish Food Codex in our country and is compulsory for all businesses. Within the scope of the Regulation on Market Surveillance, Control and Inspection and Workplace Responsibilities of Food and Food Contact Substances and Materials published on 30 May 2005, it is stated that HACCP principles should be applied within 1-3 years at the latest depending on the capacities of all food producing and selling establishments. (Türksoy \& Altıniğne, 2008, p. 607).

In addition, the HACCP system provides some advantages over other quality control applications. (Güder, 2006, p. 45):

- Easy to use and understand,

- Preventing product safety problems,

- Ability to identify potential hazards in advance rather than experience gained through error,

- Focus on resources and efforts at critical stages,

- Decreasing importance of final product inspection,

- Can be applied to food enterprises of all sizes,

- Reassuring the customer,

- Fulfillment of legal requirements,

- Systematic consideration of the development of effective control

- Can be used at every stage of the food stage.

Figure 1.1. Logical Sequencing Scheme for HACCP Implementation

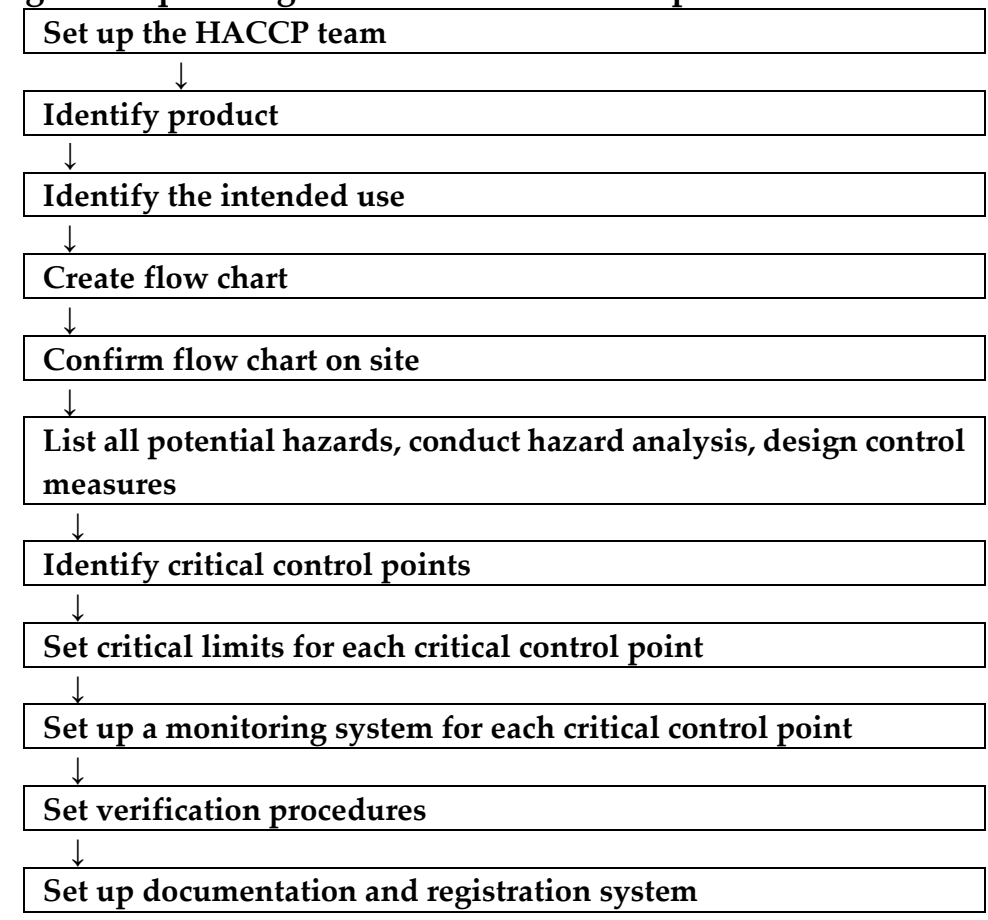

Reference: Codex Alimentarius - Food Hygiene - Basic Texts - Second Edition Annex. FAO and WHO. 


\section{Food Safety Applications in Accommodation Business}

Food must be both good looking, tasty or nutritious and the food prepared should be reliable in hotel business. For this reason, necessary arrangements must be realized in order to produce hygienic secure food and kitchen works in accordance with sanitation and hygiene rules in hotel establishments. (Aktaş, 2001). A manager should establish, maintain and support the Food Safety Control System if he wants to make production in compliance with hygiene standards and to ensure that every batch of products he produces, and sells is safe.

The slightest negligence during the preparation, cooking, storage and serving of foods can disrupt the health of hundreds and thousands of people, leading to food poisoning and death. Hygiene obtained by cleaning and sanitation in commercial kitchens is an absolute necessity. In order to minimize or even eliminate the risks that may harm human health in the mass feeding systems where food and beverage services are provided, theoretical information should be given to managers and employees, and the information provided should be supervised. Food and beverage service personnel have important responsibilities for human health. Personnel need to know the biological hazards (bacteria, mold, viruses, parasites, and yeasts) while dealing with food as well as providing healthy food. Ensuring the quality of personnel hygiene is related to the training of the personnel and the adequacy of the conditions provided to them. (Şanlier \& Tunç Hussein, 2008, p. 462).

Personnel in charge of food preparation have important responsibilities for human health. The personnel must be healthy and also hygienic of the hand, body, clothing and the equipment used when dealing with food. Tools and equipment used in the preparation of raw food and processing areas should be thoroughly cleaned and disinfected before and after use. Hot water with detergent should be used for washing the dishes and the dishes should be rinsed with plenty of water (Yaman \& Özgen, 2007, p. 29). During the preparation phase, employees should be careful about processing the product after taking precautions to ensure proper food processing. They should also be aware that foods may be exposed to food-surface contact or cross-contamination of foods with other foods. For example, tasting the food can cause cross-contamination. Workers should not touch food-contact parts of dishes, bottles or cups. In addition, the materials used in the service should always be kept clean and sanitized. There must be one person in the facility only responsible for collecting service and supplies or distributing plates. In addition, a person responsible for the supervision of the buffet and the food bar and the food service security should be careful about cross-contamination (Topal, 1996).

Recognizing that one of the most common health problems in the world is from contaminated food, the World Health Organization (WHO) recommends that consumers implement certain simple measures specifically designed to significantly reduce the risks of these diseases and protect public health. These measures, defined as the Golden Rules, are as follows: (http://www.surecdanismanlik.com/icerik.php?news id=57\&start=0\&category id=\&parent id= \&arcyear=\&arcmonth=):

1. Processed foods should be selected for safe consumption.

2. The cooking process must be applied completely and flawlessly.

3. After cooking, foods should be consumed without waiting.

4. Care should be taken in the storage of cooked foods.

5. The food must be fully and perfectly reheated.

6. Avoid contact between raw and cooked foods.

7. Washing and cleaning of hands should not be neglected.

8. The surfaces in the kitchen should be kept clean.

9. Foods should be protected from animals such as insects, rodents, pests.

10. The use of clean water should be kept in mind. 
Businesses vary in capacity and technical capabilities. Investment costs may also vary according to the project design, but hygiene rules do not change. Hygiene and sanitation concepts are especially important for sectors like tourism, service, food and beverage. (Sargin, 2005, p. 34). The creation of a hygienic environment in hotel kitchens is only achieved with the success of teamwork (Güler, 2009).

\section{Research}

Purpose, Importance and Limitations of the Research

This research on kitchen staff in accommodation establishments in the Kuşadası region is important in terms of revealing employees' views on food safety practices. This study, which is conducted only in Kuşadası region due to temporal and material constraints, is planned to be conducted for a wider sample and as a consequence more valid results are expected.

\section{Method, Population and Sample of the Research}

The questionnaire was used as the research method and Sargin's (2005) study was used in the preparation of the questionnaire. The survey consists of 2 sections. The food safety assessment form in the first section consisted of a total of 48 criteria including general cleaning ( 5 criteria), staff ( 6 criteria), purchase and delivery ( 5 criteria), storage ( 6 criteria), preparation (10 criteria), cooking and heating ( 7 criteria), service and hold (9 criteria). In the second part, there are demographic questions.

The population of the research consists of the personnel working in the kitchen departments of all accommodation establishments in Kuşadası region. According to the information received from Kuşadası Chamber of Commerce, it was determined that there were 58 enterprises and approximately 2205 kitchen staff within the scope of the research period. (https://www.kuto.org.tr/tr/kusadasi/turizmi/). The following formula was used to determine the number of samples (İlban, 2008, p. 129):

$\mathrm{n}=\mathrm{Nt}^{2} \mathrm{pq} / \mathrm{d}^{2}(\mathrm{~N}-1)+\mathrm{pq}$

$\mathrm{N}$ : Unit quantity in the mass

$\mathrm{n}$ : Sample unit quantity

$\mathrm{t}$ : Estimated confidence interval, at a given level of significance, the theoretical value found from table $t$

$\mathrm{p}$ : Incidence or possibility of realization of the event examined

q: The frequency of lack of the examined event in other words possibility of nonbeing

$\mathrm{d}$ : Accepted sample error according to frequency of occurrence

When we replace $\mathrm{N}=2205, \mathrm{t}=1,96, \mathrm{p}=0,10, \mathrm{q}=0,90, \mathrm{~d}=0,05$ in the formula, It is seen that the sample unit amount required for the research is $\mathrm{n}=139$.

450 questionnaires prepared and reproduced were delivered to the staff by the business managers and 311 usable questionnaires were obtained at the end of the response period.

The data obtained as a result of the survey conducted within the scope of the research was uploaded to SPSS 23.0 for Windows package program and various statistical analyzes were performed for the purposes of the research.

\section{Data Analysis}

The data obtained in the study are shown as frequency, percentage, arithmetic mean and standard deviations according to each question and subject area. Variance analysis was used to test the research hypotheses. In the analysis of variance, homogeneous distribution of total score means was taken into consideration as a result of Levene Test. Sheffe Multiple Comparison Test was applied to find the source of the difference between these groups. 
Each criterion in the food safety assessment form was scored according to its significance level and the percentage of the scores obtained as a result of the total score was evaluated in terms of food safety practices.

When interpreting the average of the table (Arithmetic Mean - Average), the values between 1-1.66 are considered to be "Never", the values between $1.67-2.33$ are considered to be "Sometimes", and the values between 2.34 - 3 are assumed to be "Always". These ranges, where the levels are located is obtained by dividing the series width (2) between the lowest value given to the options 1 and the highest value 3 to the number of levels (3) determined by the researcher as "Never", "Sometimes", or "Always".

\section{Research Hypotheses}

The hypotheses established in order to test whether the opinions of kitchen staff working in hotels regarding food safety practices in kitchens differ according to demographic characteristics are as follows:

H1: There is a difference in the kitchen workers' view of food safety practices according to their duties in the enterprise.

H2: There is a difference in the kitchen workers' view of food safety practices according to their age.

H3: There is a difference in the kitchen workers' perception of food safety practices according to their working hours.

H4: There is a difference in the kitchen workers' perception of food safety practices according to their working time.

\section{Finding and Comments}

In this section, the demographic information of the personnel participating in the research and the distribution of the answers given by the kitchen staff to the safe food application criteria are given and interpreted.

\section{Demographic Information of the Staff}

The distribution of the information is given related to the duties, age, service periods and educational status of the staff included in the study.

Table 1. Distribution Demographic Information of the Staff

\begin{tabular}{|c|c|c|c|}
\hline & & Frequency & Percentage \\
\hline \multirow{7}{*}{$\begin{array}{l}\text { What is your job in the } \\
\text { Business? }\end{array}$} & Head Chief & 24 & $7.7 \%$ \\
\hline & Water Chief & 35 & $11.3 \%$ \\
\hline & Section chief & 82 & $26.4 \%$ \\
\hline & Master & 94 & $30.2 \%$ \\
\hline & Apprentice & 47 & $15.1 \%$ \\
\hline & Intern & 9 & $2.9 \%$ \\
\hline & Other & 20 & $6.4 \%$ \\
\hline TOTAL & & 311 & $100.0 \%$ \\
\hline \multirow{4}{*}{ How old are you? } & 20 and under & 29 & $9.3 \%$ \\
\hline & $21-30$ & 113 & $36.3 \%$ \\
\hline & $31-40$ & 127 & $40.8 \%$ \\
\hline & 40 and above & 42 & $13.5 \%$ \\
\hline TOTAL & & 311 & $100.0 \%$ \\
\hline \multirow{4}{*}{$\begin{array}{l}\text { How long have you been } \\
\text { working? }\end{array}$} & Less than 1 year & 0 & $0.0 \%$ \\
\hline & $1-5$ years & 51 & $16.4 \%$ \\
\hline & $6-10$ years & 88 & $28.3 \%$ \\
\hline & $11-15$ years & 103 & $33.1 \%$ \\
\hline
\end{tabular}


Continuation of table 1

\begin{tabular}{|l|l|c|c|}
\hline & 16 years and over & 69 & $22.2 \%$ \\
\hline TOTAL & & $\mathbf{3 1 1}$ & $\mathbf{1 0 0 . 0} \%$ \\
\hline \multirow{4}{*}{$\begin{array}{l}\text { What's your education } \\
\text { status? }\end{array}$} & Literate & 5 & $1.6 \%$ \\
\cline { 2 - 4 } & Primary education & 80 & $25.7 \%$ \\
\cline { 2 - 4 } & $\begin{array}{l}\text { High school and } \\
\text { equivalent }\end{array}$ & 170 & $54.7 \%$ \\
\cline { 2 - 4 } & Associate Degree & 44 & $14.1 \%$ \\
\cline { 2 - 4 } & License & 7 & $2.3 \%$ \\
\cline { 2 - 4 } & Graduate & 5 & $1.6 \%$ \\
\hline TOTAL & & $\mathbf{3 1 1}$ & $\mathbf{1 0 0 . 0} \%$ \\
\hline
\end{tabular}

When the task of the personnel included in the study in Table 1 is examined; $30.2 \%$ of the staff is masters, $26.4 \%$ are section chiefs, $15.1 \%$ are apprentices, $11.3 \%$ are water chiefs, $7.7 \%$ are head chiefs and $2.9 \%$ are interns. When the age group range of the total number of personnel participating in the study is examined, it is seen that they constitute 20 and underage group with a rate of $9.3 \%$ with the least frequency. However, the fact that the most frequently repeated age group is followed by the age group of $40,8 \%$ with $31-40$ and $36.3 \%$ with 21-30 is indicative of the fact that most of the working staff are young. It is seen that $13.5 \%$ of the participants were 41 and older age group.

In Table 1, when the service period is evaluated, it is seen that $16.4 \%$ of the personnel participating in the research are $1-5$ years, $28.3 \%$ are $6-10$ years, $33.1 \%$ are $11-15$ years and $22.6 \%$ are 16 years and more. When the table regarding the education level of the personnel is examined, $1.6 \%$ of them are literate, $25.7 \%$ are primary school graduates, $54.7 \%$ are secondary school graduates, $14.1 \%$ are undergraduate and $1.6 \%$ are graduate students.

Table 2. Distribution of Information on Hotel Personnel 'Responses to General Cleaning Criteria

\begin{tabular}{|c|c|c|c|c|c|c|}
\hline & & Never & Sometimes & Always & Deviation. & Average \\
\hline \multirow{2}{*}{$\begin{array}{l}\text { A1 Cleaning in our kitchen is carried } \\
\text { out by persons responsible for } \\
\text { cleaning who do not work in the food } \\
\text { production unit. }\end{array}$} & Frequency & 40 & 8 & 263 & \multirow[b]{2}{*}{0,68} & \multirow[b]{2}{*}{2,72} \\
\hline & Percentage & 12,9 & 2,6 & 84,6 & & \\
\hline \multirow{2}{*}{$\begin{array}{l}\text { A2 Stationary tools such as benches, } \\
\text { sinks, boilers, etc. are wiped with } \\
\text { disinfecting solutions at the end of the } \\
\text { work. }\end{array}$} & Frequency & 4 & 31 & 276 & \multirow[b]{2}{*}{0,37} & \multirow[b]{2}{*}{2,87} \\
\hline & Percentage & 1,3 & 10 & 88,7 & & \\
\hline \multirow{2}{*}{$\begin{array}{l}\text { A3 The cloths used in our kitchen are } \\
\text { replaced with clean as they become } \\
\text { dirty. }\end{array}$} & Frequency & 12 & 6 & 293 & \multirow[b]{2}{*}{0,41} & \multirow[b]{2}{*}{2,90} \\
\hline & Percentage & 3,9 & 1,9 & 94,2 & & \\
\hline \multirow{2}{*}{$\begin{array}{l}\text { A4 General cleaning is done daily at } \\
\text { the end of the job. }\end{array}$} & Frequency & 1 & 23 & 287 & \multirow{2}{*}{0,28} & \multirow{2}{*}{2,92} \\
\hline & Percentage & 0,3 & 7,4 & 92,3 & & \\
\hline \multirow{2}{*}{$\begin{array}{l}\text { A5 Hard-to-reach areas such as the } \\
\text { lower, intermediate and rear parts of } \\
\text { the fixed units like sinks, benches, } \\
\text { cooking units, etc., are always cleaned. }\end{array}$} & Frequency & 2 & 38 & 271 & \multirow[b]{2}{*}{0,36} & \multirow[b]{2}{*}{2,87} \\
\hline & Percentage & 0,6 & 12,2 & 87,1 & & \\
\hline
\end{tabular}

$$
\bar{X}=1.00-1,65 \text { Never } \bar{X}=1,66-2,32 \text { Sometimes; } \bar{X}=2,33-3,00 \text { Always }
$$


The highest table average of the kitchen workers' point of view of general cleaning criteria is 2.92 , which is the value of the statement that "General cleaning is done every day at the end of the work". This value is followed by expressions with an average of 2.90 that is the value of the statement as "The cloths used in our kitchen are replaced with clean as they become dirty." It is followed by the statement "Stationary tools such as benches, sinks, boilers, etc. are wiped with disinfecting solutions at the end of the work." and "Hard-to-reach areas such as the lower, intermediate and rear parts of the fixed units like sinks, benches, cooking units, etc., are always cleaned." with an average of 2,87. This value is followed by expressions with an average of 2.72 that is the value of the statement as "Cleaning in our kitchen is carried out by persons responsible for cleaning who do not work in the food production unit".

Considering that the table average is 2.86 , it can be concluded that according to the opinions of kitchen workers in hotels, hotels believe that the general cleaning criteria are good.

Table 3. Distribution of information on personnel-related practices

\begin{tabular}{|c|c|c|c|c|c|c|}
\hline & & Never & Sometimes & Always & Deviation. & Average \\
\hline \multirow{2}{*}{$\begin{array}{l}\text { B1 Health checks of our kitchen staff } \\
\text { are carried out periodically every } 3 \\
\text { months }\end{array}$} & Frequency & 2 & 40 & 269 & \multirow[b]{2}{*}{0,37} & \multirow[b]{2}{*}{2,86} \\
\hline & Percentage & 0,6 & 12,9 & 86,5 & & \\
\hline \multirow{2}{*}{$\begin{array}{l}\text { B2 If one of the staff is ill, he is not } \\
\text { allowed to work in the kitchen. }\end{array}$} & Frequency & 54 & 33 & 224 & \multirow{2}{*}{0,77} & \multirow{2}{*}{2,55} \\
\hline & Percentage & 17,4 & 10,6 & 72 & & \\
\hline \multirow{2}{*}{$\begin{array}{l}\text { B3 Uniforms of our kitchen personnel } \\
\text { are replaced with clean ones every day. }\end{array}$} & Frequency & 1 & 8 & 302 & \multirow{2}{*}{0,19} & \multirow{2}{*}{2,97} \\
\hline & Percentage & 0,3 & 2,6 & 97,1 & & \\
\hline \multirow{2}{*}{$\begin{array}{l}\text { B4 Kitchen staff does not smoke while } \\
\text { on duty. }\end{array}$} & Frequency & 79 & 4 & 228 & \multirow{2}{*}{0,87} & \multirow{2}{*}{2,48} \\
\hline & Percentage & 25,4 & 1,3 & 73,3 & & \\
\hline \multirow{2}{*}{$\begin{array}{l}\text { B5 Our kitchen staff always use caps, } \\
\text { caps and gloves when working }\end{array}$} & Frequency & 0 & 16 & 295 & \multirow{2}{*}{0,22} & \multirow{2}{*}{2,95} \\
\hline & Percentage & 0 & 5,1 & 94,9 & & \\
\hline \multirow{2}{*}{$\begin{array}{l}\text { B6 Our kitchen staff does not use } \\
\text { aprons as towels when working }\end{array}$} & Frequency & 2 & 16 & 293 & \multirow{2}{*}{0,27} & \multirow{2}{*}{2,94} \\
\hline & Percentage & 0,6 & 5,1 & 94,2 & & \\
\hline
\end{tabular}

$$
\bar{X}=1.00-1,65 \text { Never } \bar{X}=1,66-2,32 \text { Sometimes; } \bar{X}=2,33-3,00 \text { Always }
$$

The value of the statement "The uniforms of our kitchen personnel are washed in the institution's laundry and replaced with clean every day" which has the highest table average regarding the point of view of the kitchen employees in hotels regarding the criteria related to personnel practices is 2.97. This value is followed by expressions with an average of 2.95 that is the value of the statement as "Our kitchen staff always uses caps, caps and gloves when working". It is followed by the statement "Our kitchen staff does not use aprons as towels when working" with the value of 2,94 and the statement as "Health checks of our kitchen staff are carried out periodically every 3 months" with the value of 2,86.

Considering that the overall average of the table is 2.79 , it can be concluded that the kitchen staff in the hotels believe that the hotels are good in terms of the criteria regarding the applications for the general staff. However, the statement that "the person who is ill in our kitchen staff is not employed in the kitchen" is below the general average can be interpreted to mean that employees are sometimes employed even if they are sick. 
Table 4. Distribution of Information on Purchasing and Receiving Practices of Kitchen Staff

\begin{tabular}{|c|c|c|c|c|c|c|}
\hline & & Never & Sometimes & Always & S.Deviation & Average \\
\hline \multirow{2}{*}{$\begin{array}{l}\text { C1 In the kitchen I work, food is } \\
\text { purchased from reliable sources. }\end{array}$} & Frequency & 0 & 7 & 304 & \multirow{2}{*}{0,15} & \multirow{2}{*}{2,98} \\
\hline & Percentage & 0 & 2,3 & 97,7 & & \\
\hline \multirow{2}{*}{$\begin{array}{l}\text { C2 When packing the food to the } \\
\text { establishment, it is ensured that } \\
\text { the packaging and packages are } \\
\text { clean and sound. }\end{array}$} & Frequency & 0 & 5 & 306 & \multirow[b]{2}{*}{0,13} & \multirow[b]{2}{*}{2,98} \\
\hline & Percentage & 0 & 1,6 & 98,4 & & \\
\hline \multirow{2}{*}{$\begin{array}{l}\text { C3 In our kitchen, meat, fish, } \\
\text { chicken, milk and so on. foods are } \\
\text { delivered at } 50 \mathrm{C} \text { or below. }\end{array}$} & Frequency & 3 & 14 & 294 & \multirow[b]{2}{*}{0,28} & \multirow[b]{2}{*}{2,94} \\
\hline & Percentage & 1 & 4,5 & 94,5 & & \\
\hline \multirow{2}{*}{$\begin{array}{l}\text { C4 Purchased food that is bruised } \\
\text { or dirty (returned) is returned. }\end{array}$} & Frequency & 9 & 21 & 281 & \multirow{2}{*}{0,41} & \multirow{2}{*}{2,87} \\
\hline & Percentage & 2,9 & 6,8 & 90,4 & & \\
\hline \multirow{2}{*}{$\begin{array}{l}\text { C5 Frozen food purchased in our } \\
\text { kitchen is measured with a } \\
\text { thermometer at }-18^{\circ} \mathrm{C} \text { and below. }\end{array}$} & Frequency & 2 & 22 & 287 & \multirow[b]{2}{*}{0,30} & \multirow[b]{2}{*}{2,92} \\
\hline & Percentage & 0,6 & 7,1 & 92,3 & & \\
\hline
\end{tabular}

$$
\bar{X}=1.00-1,65 \text { Never } \bar{X}=1,66-2,32 \text { Sometimes; } \bar{X}=2,33-3,00 \text { Always }
$$

It is seen that the table averages regarding the point of view of kitchen workers in hotels regarding the criteria for purchasing and receiving applications are very high in general. Considering that the overall average of the table is 2,94 , it can be concluded that the kitchen staff in the hotels believe that the hotels are good in terms of the criteria regarding the applications for buying and receiving. According to these results, purchasing and receiving activities are carried out in accordance with the general health and hygiene rules in the participating hotels.

Table 5. Distribution of Information on Storage Practices of Kitchen Staff

\begin{tabular}{|c|c|c|c|c|c|c|}
\hline & & Never & Sometimes & Always & S.Deviation & Average \\
\hline \multirow{2}{*}{$\begin{array}{l}\text { D1 Foods in our warehouses do } \\
\text { not come into contact with each } \\
\text { other. }\end{array}$} & Frequency & 33 & 26 & 252 & \multirow[b]{2}{*}{0,65} & \multirow[b]{2}{*}{2,70} \\
\hline & Percentage & 10,6 & 8,4 & 81 & & \\
\hline \multirow{2}{*}{$\begin{array}{l}\text { D2 Cooked foods and raw foods } \\
\text { are stored in the same areas in our } \\
\text { kitchen. }\end{array}$} & Frequency & 204 & 40 & 67 & \multirow[b]{2}{*}{0,82} & \multirow[b]{2}{*}{1,56} \\
\hline & Percentage & 65,6 & 12,9 & 21,5 & & \\
\hline \multirow{2}{*}{$\begin{array}{l}\text { D3 Frozen foods are stored at }-18 \\
{ }^{\circ} \mathrm{C} \text {. }\end{array}$} & Frequency & 2 & 15 & 294 & \multirow{2}{*}{0,27} & \multirow{2}{*}{2,94} \\
\hline & Percentage & 0,6 & 4,8 & 94,5 & & \\
\hline \multirow{2}{*}{$\begin{array}{l}\text { D4 Dry storages of the kitchen are } \\
\text { kept at temperatures below }+15 / \\
+20^{\circ} \mathrm{C} \text {. }\end{array}$} & Frequency & 3 & 14 & 294 & \multirow[b]{2}{*}{0,28} & \multirow[b]{2}{*}{2,94} \\
\hline & Percentage & 1 & 4,5 & 94,5 & & \\
\hline \multirow{2}{*}{$\begin{array}{l}\text { D5 Meat, fish, chicken, milk and } \\
\text { etc. are stored at temperatures } \\
\text { below }+5{ }^{\circ} \mathrm{C} \text {. }\end{array}$} & Frequency & 4 & 17 & 290 & \multirow[b]{2}{*}{0,32} & \multirow[b]{2}{*}{2,92} \\
\hline & Percentage & 1,3 & 5,5 & 93,2 & & \\
\hline \multirow{2}{*}{$\begin{array}{l}\text { D6 Foods in cold stores are stored } \\
\text { with closed lids, aluminum foil } \\
\text { and plastic film stretches. }\end{array}$} & Frequency & 1 & 14 & 296 & \multirow[b]{2}{*}{0,24} & \multirow[b]{2}{*}{2,95} \\
\hline & Percentage & 0,3 & 4,5 & 95,2 & & \\
\hline
\end{tabular}

$$
\bar{X}=1.00-1,65 \text { Never } \bar{X}=1,66-2,32 \text { Sometimes; } \bar{X}=2,33-3,00 \text { Always }
$$

Having the highest table average regarding the point of view of kitchen workers in hotels about the criteria for storage practices is 2.95 for the statement "The food contained in cold stores is stored with closed lid, aluminum foil and plastic film stretches". This value is 
followed by 2,94 for the statement as "Frozen foods are stored at - $18 \mathrm{C}$ " and the value of 2,92 for the statement as "Meat, fish, chicken, milk, and etc. are stored at temperatures below $+5 C^{\prime \prime}$ ", the value of 2,70 for the statement as "Foods in our warehouses do not come into contact with each other" and the value of 1,56 for the statement as "Cooked foods and raw foods are stored in the same areas in our kitchen." Considering that the overall average of the table is 2.67, it can be concluded that the kitchen staff in the hotels believe that the criteria for storage practices are good. In the table, the average of the expression of "Cooked foods and raw foods stored in the same areas in our kitchen." is 1.56. However considering that the judiciary contains negative statements, it can be interpreted that kitchen workers believe that raw and cooked foods are not stored in the same place since the evaluation of the average of the statement is "never".

Table 6. Distribution of Kitchen Staff on Food Preparation Practices

\begin{tabular}{|c|c|c|c|c|c|c|}
\hline & & Never & Sometimes & Always & S.Deviation & Average \\
\hline \multirow{2}{*}{$\begin{array}{l}\text { E1 In our kitchen, meat, } \\
\text { vegetables and doughs are } \\
\text { prepared in different } \\
\text { preparation units or benches. } \\
\end{array}$} & Frequency & 2 & 16 & 293 & \multirow[b]{2}{*}{0,27} & \multirow[b]{2}{*}{2,94} \\
\hline & Percentage & 0,6 & 5,1 & 94,2 & & \\
\hline \multirow{2}{*}{$\begin{array}{l}\text { E2 In our kitchen, raw and } \\
\text { cooked foods are prepared in the } \\
\text { same places or benches. }\end{array}$} & Frequency & 197 & 22 & 92 & \multirow{2}{*}{0,90} & \multirow{2}{*}{1,66} \\
\hline & Percentage & 63,3 & 7,1 & 29,6 & & \\
\hline \multirow{2}{*}{$\begin{array}{l}\text { E3 In our kitchen, different } \\
\text { chopping boards are used for } \\
\text { meat, fish, chicken and } \\
\text { vegetables. }\end{array}$} & Frequency & 3 & 28 & 280 & \multirow[b]{2}{*}{0,34} & \multirow[b]{2}{*}{2,89} \\
\hline & Percentage & 1 & 9 & 90 & & \\
\hline \multirow{2}{*}{$\begin{array}{l}\text { E4 In our kitchen, different } \\
\text { chopping knives are used for } \\
\text { meat, fish, chicken and } \\
\text { vegetables. }\end{array}$} & Frequency & 3 & 42 & 266 & \multirow[b]{2}{*}{0,39} & \multirow[b]{2}{*}{2,85} \\
\hline & Percentage & 1 & 13,5 & 85,5 & & \\
\hline \multirow{2}{*}{$\begin{array}{l}\text { E5 In our kitchen, meat, milk, } \\
\text { eggs, etc. foods are prepared } \\
\text { quickly and aren't kept at room } \\
\text { temperature for longer }\end{array}$} & Frequency & 4 & 24 & 283 & \multirow[b]{2}{*}{0,34} & \multirow[b]{2}{*}{2,90} \\
\hline & Percentage & 1,3 & 7,7 & 91 & & \\
\hline \multirow{2}{*}{$\begin{array}{l}\text { E6 In our kitchen, vegetables and } \\
\text { fruits are washed thoroughly } \\
\text { under running water. }\end{array}$} & Frequency & 1 & 6 & 304 & \multirow[b]{2}{*}{0,18} & \multirow[b]{2}{*}{2,97} \\
\hline & Percentage & 0,3 & 1,9 & 97,7 & & \\
\hline \multirow{2}{*}{$\begin{array}{l}\text { E7 Disinfectant is used in wash } \\
\text { water of vegetables and fruits in } \\
\text { our kitchen. }\end{array}$} & Frequency & 12 & 28 & 271 & \multirow[b]{2}{*}{0,47} & \multirow[b]{2}{*}{2,83} \\
\hline & Percentage & 3,9 & 9 & 87,1 & & \\
\hline \multirow{2}{*}{$\begin{array}{l}\text { E8 In our kitchen, meat mincing } \\
\text { machines are washed and rinsed } \\
\text { with hot soapy water and } \\
\text { disinfected every day. }\end{array}$} & Frequency & 9 & 24 & 278 & \multirow[b]{2}{*}{0,42} & \multirow[b]{2}{*}{2,87} \\
\hline & Percentage & 2,9 & 7,7 & 89,4 & & \\
\hline \multirow{2}{*}{$\begin{array}{l}\text { E9 In our kitchen, defrosting is } \\
\text { done at room temperature. }\end{array}$} & Frequency & 106 & 46 & 159 & \multirow{2}{*}{0,91} & \multirow{2}{*}{2,17} \\
\hline & Percentage & 34,1 & 14,8 & 51,1 & & \\
\hline \multirow{2}{*}{$\begin{array}{l}\text { E10 Defrost food is frozen again } \\
\text { in our kitchen. }\end{array}$} & Frequency & 212 & 29 & 70 & \multirow{2}{*}{0,84} & \multirow{2}{*}{1,54} \\
\hline & Percentage & 68,2 & 9,3 & 22,5 & & \\
\hline
\end{tabular}

$$
\bar{X}=1.00-1,65 \text { Never; } \bar{X}=1,66-2,32 \text { Sometimes; } \bar{X}=2,33-3,00 \text { Always }
$$

It is seen that the general table average regarding the viewpoint of the kitchen workers in hotels regarding the criteria for food preparation related practices is high. Considering that 
the overall average of the table is 2.56 , it can be concluded that the kitchen staff in the hotels believe that the hotels are good in terms of the criteria regarding the practices for preparing food according to the opinions. Considering that the statement as "defrost food is frozen again in our kitchen" in the table contains negative judgments and the average is 1.54, it can be interpreted that defrost foods are never frozen. However, the average of "Defrosting of food in our kitchen is done at room temperature." is 2,17 means that the average food defrosting process in hotels is sometimes at room temperature.

According to these results, instruments are used according to the characteristics of the product in the food preparation activities in the participating hotels and instead of using a single tool for products, suitable tools are used for each product. In addition, the preparation of frozen products is generally appropriate in accordance with health rules.

Table 7. Distribution of Information on Cooking and Heating Practices of Kitchen Staff

\begin{tabular}{|c|c|c|c|c|c|c|}
\hline & & Never & Sometimes & Always & S.Deviation & Average \\
\hline \multirow{2}{*}{$\begin{array}{l}\text { F1 In our kitchen, cooking } \\
\text { utensils are cleaned and } \\
\text { disinfected after each use by } \\
\text { the person responsible for } \\
\text { their cleaning. }\end{array}$} & Frequency & 2 & 16 & 293 & \multirow[b]{2}{*}{0,27} & \multirow[b]{2}{*}{2,94} \\
\hline & Percentage & 0,6 & 5,1 & 94,2 & & \\
\hline \multirow{2}{*}{$\begin{array}{l}\text { F2 Food thermometers are } \\
\text { used in our kitchen during the } \\
\text { cooking process. }\end{array}$} & Frequency & 4 & 45 & 262 & \multirow[b]{2}{*}{0,41} & \multirow[b]{2}{*}{2,83} \\
\hline & Percentage & 1,3 & 14,5 & 84,2 & & \\
\hline \multirow{2}{*}{$\begin{array}{l}\text { F3 In our kitchen, meals with } \\
\text { potentially risky foods are } \\
\text { allowed to reach internal } \\
\text { temperatures of }+65 \mathrm{C} \text { and } \\
\text { above and wait for at least two } \\
\text { minutes. }\end{array}$} & Frequency & 2 & 13 & 296 & \multirow[b]{2}{*}{0,25} & \multirow[b]{2}{*}{2,95} \\
\hline & Percentage & 0,6 & 4,2 & 95,2 & & \\
\hline \multirow{2}{*}{$\begin{array}{l}\text { F4 In our kitchen, the cooking } \\
\text { process is finished (without a } \\
\text { break). }\end{array}$} & Frequency & 1 & 35 & 275 & \multirow[b]{2}{*}{0,33} & \multirow[b]{2}{*}{2,88} \\
\hline & Percentage & 0,3 & 11,3 & 88,4 & & \\
\hline \multirow{2}{*}{$\begin{array}{l}\text { F5 The taste control of the } \\
\text { dishes cooked in our kitchen is } \\
\text { done with healthy methods. }\end{array}$} & Frequency & 0 & 9 & 302 & \multirow[b]{2}{*}{0,17} & \multirow[b]{2}{*}{2,97} \\
\hline & Percentage & 0 & 2,9 & 97,1 & & \\
\hline \multirow{2}{*}{$\begin{array}{l}\text { F6 In our kitchen, small pieces } \\
\text { of food (frozen vegetables, } \\
\text { meatballs, etc.) are directly } \\
\text { cooked in their frozen form. }\end{array}$} & Frequency & 123 & 52 & 136 & \multirow[b]{2}{*}{0,91} & \multirow[b]{2}{*}{2,04} \\
\hline & Percentage & 39,5 & 16,7 & 43,7 & & \\
\hline \multirow{2}{*}{$\begin{array}{l}\text { F7 Our kitchen staff does not } \\
\text { touch the food by bare hand. }\end{array}$} & Frequency & 94 & 21 & 196 & \multirow{2}{*}{0,91} & \multirow{2}{*}{2,33} \\
\hline & Percentage & 30,2 & 6,8 & 63 & & \\
\hline
\end{tabular}

$$
\bar{X}=1.00-1,65 \text { Never; } \bar{X}=1,66-2,32 \text { Sometimes; } \bar{X}=2,33-3,00 \text { Always }
$$

The value of the statement "The taste control of the dishes cooked in our kitchen is done with healthy methods." is 2,97, which has the highest table average of view of the kitchen workers in hotels regarding the criteria for cooking and heating applications. This value is followed by 2,95 with the statement "In our kitchen, meals with potentially risky foods are allowed to reach internal temperatures of $+65 \mathrm{C}$ and above and wait for at least two minutes.", then the value of 2,94 with the statement "In our kitchen, cooking utensils are cleaned and disinfected after each use by the person responsible for their cleaning.". The statement as "In our kitchen, the cooking process is finished (without a break)" has 2,88 value. The statement as "Food thermometers are 
used in our kitchen during the cooking process." has 2,83 value. This value is followed by 2,33 with the statement as "Our kitchen staff does not touch the food by bare hand" and the value of 2,04 with the statement as "In our kitchen, small pieces of food (frozen vegetables, meatballs, etc.) are directly cooked in their frozen form." Considering that the overall average of the table is 2.70 , it can be concluded that, according to the opinions of the kitchen staff in the hotels, they believe that the criteria for cooking and heating applications are good. However since the value of the statement as "In our kitchen, small pieces of food (frozen vegetables, meatballs, etc.) are directly cooked in their frozen form." 2,04, it can be interpreted that the belief that piecemeal food is not always cooked with frozen form is dominant.

Table 8. Distribution of kitchen personnel regarding service and holding applications

\begin{tabular}{|c|c|c|c|c|c|c|}
\hline & & Never & Sometimes & Always & S.Deviation & Average \\
\hline \multirow{2}{*}{$\begin{array}{l}\text { G1 Bain-marie, chafing dish, etc. the } \\
\text { food is kept warm in the hot holding } \\
\text { units. }\end{array}$} & Frequency & 3 & 8 & 300 & \multirow[b]{2}{*}{0,25} & \multirow[b]{2}{*}{2,96} \\
\hline & Percentage & 1 & 2,6 & 96,5 & & \\
\hline \multirow{2}{*}{$\begin{array}{l}\text { G2 Freshly cooked food is } \\
\text { supplemented on the reduced food } \\
\text { or food pending during service. }\end{array}$} & Frequency & 150 & 33 & 128 & \multirow[b]{2}{*}{0,94} & \multirow[b]{2}{*}{1,93} \\
\hline & Percentage & 48,2 & 10,6 & 41,2 & & \\
\hline \multirow{2}{*}{$\begin{array}{l}\text { G3 The temperature of the hot } \\
\text { holding unit in our kitchen is } \\
\text { checked before each service. }\end{array}$} & Frequency & 4 & 17 & 290 & \multirow[b]{2}{*}{0,32} & \multirow[b]{2}{*}{2,92} \\
\hline & Percentage & 1,3 & 5,5 & 93,2 & & \\
\hline \multirow{2}{*}{$\begin{array}{l}\text { G4 Food served cold in our kitchen is } \\
\text { served with a cooling mechanism in } \\
\text { buffet services and is not kept for } \\
\text { more than } 2 \text { hours. }\end{array}$} & Frequency & 9 & 21 & 281 & \multirow[b]{2}{*}{0,41} & \multirow[b]{2}{*}{2,87} \\
\hline & Percentage & 2,9 & 6,8 & 90,4 & & \\
\hline \multirow{2}{*}{$\begin{array}{l}\text { G5 During service, temperature } \\
\text { measurements are recorded with } \\
\text { food thermometers. }\end{array}$} & Frequency & 3 & 32 & 276 & \multirow[b]{2}{*}{0,36} & \multirow[b]{2}{*}{2,88} \\
\hline & Percentage & 1 & 10,3 & 88,7 & & \\
\hline \multirow{2}{*}{$\begin{array}{l}\text { G6 Cooked dishes are served within } \\
2 \text { hours in our Kitchen. }\end{array}$} & Frequency & 2 & 41 & 268 & \multirow{2}{*}{0,37} & \multirow{2}{*}{2,86} \\
\hline & Percentage & 0,6 & 13,2 & 86,2 & & \\
\hline \multirow{2}{*}{$\begin{array}{l}\text { G7 In our kitchen, food is kept closed } \\
\text { until served. }\end{array}$} & \begin{tabular}{|l|} 
Frequency \\
\end{tabular} & 3 & 11 & 297 & \multirow{2}{*}{0,27} & \multirow{2}{*}{2,95} \\
\hline & Percentage & 1 & 3,5 & 95,5 & & \\
\hline \multirow{2}{*}{$\begin{array}{l}\text { G8 During service, the appearance of } \\
\text { the food is corrected by hand. }\end{array}$} & Frequency & 229 & 27 & 55 & \multirow{2}{*}{0,78} & \multirow{2}{*}{1,44} \\
\hline & \begin{tabular}{|l|} 
Percentage \\
\end{tabular} & 73,6 & 8,7 & 17,7 & & \\
\hline \multirow{2}{*}{$\begin{array}{l}\text { G9 Foods returned from service in } \\
\text { our kitchen are re-evaluated. }\end{array}$} & Frequency & 155 & 91 & 65 & \multirow{2}{*}{0,79} & \multirow{2}{*}{1,71} \\
\hline & Percentage & 49,8 & 29,3 & 20,9 & & \\
\hline
\end{tabular}

$$
\bar{X}=1.00-1,65 \text { Never; } \bar{X}=1,66-2,32 \text { Sometimes; } \bar{X}=2,33-3,00 \text { Always }
$$

It is seen that the general table average regarding the point of view of kitchen employees in hotels regarding their criteria for service and holding practices is high. Considering that the general average of the table is 2.50 , it can be concluded that according to the opinions of the kitchen employees in the hotels, they believe that the hotels are good in terms of their criteria for service and holding applications.

"The appearance of food during service is corrected by hand" in the table contains negative judgment and the average is 1.44 can be interpreted that food is never corrected by hand during serving since it was stated as "never". However, the average value of 1.71 in the statement "The food returned from the service is re-evaluated" means that food returned from the service is sometimes re-evaluated in hotels. Likewise, the average of 1.93 on the statement "Reduced food or food waiting during service is supplemented with freshly made 
food" can sometimes be interpreted as the addition of new and hot dishes on the pending and diminishing meals in hotels.

\section{Results}

The place and importance of the food and beverage department within the organizational structure of the hotel enterprises varies according to the size and quality of the hotel. As the size of hotels and the number of stars increases, the importance of the food and beverage department also increases. Since the food and beverage department and the service department are the centers that generate the most income after the rooms section, they are called revenue centers. The kitchen, which is the central part of the food and beverage department, has to be planned in such a way as to ensure an efficient, hygienic and modern production flow due to the complex tasks. The physical location and planning of the kitchen, which is the heart of the hotel business, the personal hygiene of the staff working in the kitchen, the selection and hygiene of tools and equipment is of utmost importance.

Anova analyzes were conducted in order to determine whether the kitchen workers in the hotels of Kuşadası region differed according to the demographic characteristics of their views on food safety practices in the kitchen. The hypotheses established and the results of the ANOVA analysis of the hypotheses are as follows:

Table 9. Results of the Anova Analysis of Hypotheses

\begin{tabular}{|c|l|l|l|l|}
\hline & df & $\mathbf{F}$ & $\mathbf{p}$ & Result \\
\hline $\begin{array}{c}\text { "H1-2: There is a difference in the view of kitchen } \\
\text { personnel towards the applications according to their } \\
\text { duties in the enterprise." }\end{array}$ & 6,304 & 2,174 & 0,045 & Acceptance \\
\hline $\begin{array}{c}\text { "H3-6: There is a difference in the kitchen workers' view } \\
\text { of the applications for cooking and heating activities } \\
\text { according to their working time." }\end{array}$ & 3,307 & 2,666 & 0,048 & Acceptance \\
\hline $\begin{array}{c}\text { "H4-7: There is a difference in the view of kitchen } \\
\text { workers about the service and holding activities } \\
\text { according to their working hours." }\end{array}$ & 5,305 & 3,931 & 0,002 & Acceptance \\
\hline
\end{tabular}

As a result of the ANOVA analysis, it was found that there was a statistically significant difference $(\mathrm{p}=0,045<0,05)$ in the view of only the personnel oriented applications stating whether the kitchen workers' views of food safety practices in the kitchen differ according to their duties in the enterprise. As a result of the Sheffe test conducted to determine the source of the difference, it is seen that the difference is caused by the master and apprentice who created the difference according to the task in the enterprise.

As a result of the ANOVA analysis of whether the kitchen workers in the hotel's view of the food safety practices in the kitchen differ according to their duties in the enterprise, other subhypotheses were rejected since $p$ values of other applications ( $p>0.05)$ were not statistically significant.

Since the $p$ values ( $p>0.05$ ) were not statistically significant, the lower hypotheses of H2 were rejected as a result of the ANOVA analysis for determining whether perceptions of the kitchen staff in the hotels related with food safety practices in the kitchen differ according to their age.

As a result of the ANOVA analysis, whether the perceptions of the kitchen workers in the hotels' related with the food safety practices in the kitchen differ according to the working hours in the enterprise, it was found that there was a statistically significant difference only in the view of cooking and heating activities $(\mathrm{p}=0.048<0.05)$. As a result of the Sheffe test conducted to 
determine the source of the difference, it is seen that it is caused by employees who make the difference between 6-10 and 11-15 years.

Other sub-hypotheses were rejected because the $p$ values $(p>0.05)$ found were not statistically significant in the results of the ANOVA analysis on whether the kitchen workers' perceptions about the food safety practices in the kitchen differed according to the working time in the enterprise.

It was found that there was a statistically significant difference only in their view of service and holding activities $(p=0.002<0.05)$ as a result of the ANOVA analysis about whether the kitchen workers' perception of food safety practices in the kitchen did not differ according to their educational background. As a result of the Sheffe test carried out to determine the source of the difference, it was seen that this difference was caused by being literate and having education at primary and secondary level.

Other sub-hypotheses were rejected because the $p$ values ( $p>0.05)$ found were not statistically significant in the results of the ANOVA analysis on whether the kitchen workers' perceptions about the food safety practices in the kitchen differed according to the working time in the enterprise.

\section{References}

Aktaş, A. (2001). Ağırlama Hizmet İşletmelerinde Yiyecek Ve İçecek Yönetimi. Livane Matbaası, Antalya.

Codex Alimentarius, (2001). Food Hygiene - Basic Texts - Second Edition Annex. FAO ve WHO. Rome, http://www.fao.org/DOCREP/005/Y1579E/y1579e00.htm, Erişim: 23.07.2019.

Giray, H. \& Soysal, A. (2007). Türkiye'de Gıda Güvenliği ve Mevzuatı, TSK Koruyucu Hekimlik Bülteni, 6(6):485-490.

Giray, H., Akın, A., Dölekoğlu, C. \& Gün, S. (2006). Gıda Güvenliği ve AB Uyum Sürecinde Türkiye'de Yaşanan Gelişmeler, Türkiye VII. Tarım Ekonomisi Kongresi, Antalya, ss.971979.

Güder, G. (2006). Avrupa Birliği Gıda Güvenliği Politikası ve Üyelik Sürecinde Türkiye’ye Yansımaları, Avrupa Birliği İle İlişkiler Genel Müdürlüğü, Yayımlanmış Uzmanlık Tezi, Ankara.

Güler, S. (2009). Rekabet Avantajı Yaratmada Otel Mutfaklarında Gıda Güvenliği Sistemlerinin Kullanılması, 3. Ulusal Gastronomi Sempozyumu, Antalya.

Hacıoğlu, N. ve Girgin, G.K. (2008). HACCP Sisteminin Otellerin Mutfak Çalışanları Tarafından Değerlendirilmesi: Beş Yıldızlı Otel İşletmelerinde Bir Araştırma, Dokuz Eylül Üniversitesi İşletme Fakültesi Dergisi, 9(2):281-301.

İlban, M. (2008). Seyahat Acenta Yöneticilerinin Destinasyon Marka İmajı Algıları Üzerine Bir Araştırma, Ege Akademik Bakış Dergisi, 8(1):121-152

Karaali, A. (2003). Gıda İşletmelerinde HACCP Uygulamaları ve Denetimi, Refik Saydam Hıfzıssıhha Merkezi Başkanlığı, Hıfzıssıhha Mektebi Müdürlüğü Yayınları, Ankara.

Sargın, Y. (2005). Ankara'daki Dört ve Beş Yıldızlı Otellerde Çalışan Yiyecek ve İçecek Personelinin Hijyen Bilgileri ve Uygulamalarının İncelenmesi, Ankara Üniversitesi Fen Bilimleri Enstitüsü Ev Ekonomisi (Beslenme Bilimleri) Anabilim Dalı, Yayımlanmamış Yüksek Lisans Tezi, Ankara.

Şahin, M. (2001). Sürdürülebilir Gıda Kalitesi ve Gıda Güvenliği, Ondokuz Mayıs Üniversitesi Ziraat Fakültesi, Yayımlanmamış Bitirme Tezi, Samsun.

Şanlıer, N. ve Tunç Hussein, A. (2008). Yiyecek-İçecek Hizmeti Veren Otel Mutfakları ve Personelinin Hijyen Yönünden Değerlendirilmesi: Ankara İli Örneği, Kastamonu Eğitim Dergisi, 16(2):461-468. 
Şimşek, O.U. (2006). Üç, Dört, Beş Yıldızlı Otellerde Çalışan Mutfak Personelinin Görüşleri Doğrultusunda Çalıştıkları Mutfaklardaki Gıda Güvenliği Uygulamalarının Değerlendirilmesi, Gazi Üniversitesi Eğitim Bilimleri Enstitüsü Aile Ekonomisi ve Beslenme Eğitimi Anabilim Dalı, Yayımlanmamış Yüksek Lisans Tezi, Ankara.

Topal, R.Ş. (1996). Gıda Güvenliği ve Kalite Yönetim Sistemleri. TÜBİTAK -Marmara Araştırma Merkezi. Gebze, Kocaeli.

Türksoy, A. ve Altıniğne, N. (2008). Konaklama İşletmelerinde Gıda Güvenliği ve Çeşme İlçesinde Yer Alan Turizm Belgeli Konaklama Tesislerinde Gıda Güvenliği Uygulamalarının Değerlendirilmesi, Ege Akademik Bakış Dergisi, 8(2):605-629.

Yaman, M. ve Özgen, L. (2007). Üniversite Öğrencilerinin Yurtlarındaki Besin Hijyeni Yaklaşımları ve Besin Hazırlama Uygulamaları, Gazi Üniversitesi Endüstriyel Sanatlar Eğitim Fakültesi Dergisi, Sayı 20, s.28-38.

http://www.surecdanismanlik.com/icerik.php?news $\mathrm{id}=57 \&$ start=0\&category $\mathrm{id}=\&$ parent $\mathrm{id}=\&$ arcyear=\&arcmonth $=$ Erişim 03.11.2018. 